\title{
Seminar Program Kerja Desa
}

\author{
Nur Azizah Ainun Razak \\ NIM : 9173770410043 \\ Email : andiainun606@gmail.com
}

\section{Bentuk Kegiatan}

Seminar program kerja mahasiswa KKLP (kuliah kerja lapang plus) Stie Stkip Yapti Jeneponto

\section{Lokasi}

Aula Kantor Desa Balang Loe Tarowang

\section{Hari/Tanggal dan Waktu}

Pada Hari Rabu Tanggal 23 September 2020

Jam 09:00 wib

\section{Peserta yang Dilibatkan}

Seminar ini melibatkan

Panitia,pembimbing, Kepala

Desa,Bapak Bhabinkamtimnas,ketua pkk,kader posyandu,kepala dusun, rk,ketua bpd, tokoh masyarakat dan mahasiswa kklp.

\section{Alasan Diadakannya}

Kegiatan ini di adakan dalam rangka pemaparan program kerja mahasiswa KKLP di Desa Balangloe tarowang kepada masyarakat setempat.

\section{Tujuan dan Manfaat}

Tujuan Diadakan Seminar ini untuk melaksanakan program kerja.
Manfaat memunculkan sebuah rasa kebersamaan didalamnya.

\section{Produk Kegiatan (Jika Ada)}

Papan Nama Dusun Sebanyak 4 (Empat) Pembagian hanzanitiser sebanyak 130botol dan

Pembagian masker sebanyak 150 lembar

\section{Deskripsi Kegiatan}

Mahasiswa kuliah kerja lapang plus (KKLP) Stie Stkip Yapti Jeneponto angkatan XXII mengadakan program kerja KKLP dikantor Desa Balangloe Tarowang Kec.Tarowang Kab.Bantaeng Jeneponto Kegiatan tersebut diawali dengan Sambutan Koordinator Desa Balangloe Tarowang ,Panitia KKLP, Dosen Pembimbing,Dan Pembukaan acara oleh Kepala Desa Balang loe Tarowang, adapapun progra $\mathrm{m}$ kerja yang dosampaikan ialah program fisik ( papan Nama dusun sebanyak 4 Buah), pembagian Handzanitezier sebanyak 130 botol dan pembagian masker sebanyak 150 lembar. Sedangkan program fisik

9. Referensi Wajib

- HERIANTO, H., \& Amir, A. S. (2020, September 10). Pedoman Pelaksanaan Kuliah Kerja Lapangan Plus (KKLP) Mahasiswa STIE dan STKIP YAPTI Jeneponto. https://doi.org/10.31219/osf.io/7dvpk 